\title{
16. ve 18. Yüzyıllarda Osmanlı Yönetiminde Nahçıvan Sancağı Sadık Müfit Bilge*
}

\section{Özet}

Osmanlı-Safevî mücadeleleri sırasında birçok kez el değiştiren ve kanlı savaşlara sahne olan Nahçıvan, ilki 1588-1603, ikincisi 1724-1735 yılları arasında olmak üzere 2 defa sancak olarak Osmanlı yönetiminde kaldı. Nahçıvan, Revân eyâletinin bir sancağıydı.1588-1603 yılları arasında Revân Eyaleti, "Revan ve Nahcıvan Eyaleti" olarak da adlandırıldı. Nahcıvan Sancağı, 12 mahallesi bulunan Nahcıvan ile Gökçe, Mevâzi-i Hatun, Dereşahbûz, Arslanlu, Karabağ, Dereçam, Bazarçay nahiyelerinden oluşmaktaydı. Ekonomisi tarım ve hayvancilığa dayalı olan Nahçıvan sancağında bazı köylerin gelirleri ile ihtisab, boyahâne, şemhâne, bâc-ı bazar, tamgâ-i siyah, Nahçıvan tuz ocakları gelirleri ve cizye vergisi pâdişâh hâslarına dâhildi. Bazı köyler ise ulûfeleri hazîneye kalmak şartı ile Revân ve Nahçıvan kalelerindeki askerlere timar ve zeâmet olarak verilmişti. Osmanlı yönetimi sırasında şehirde çeşitli eserler (cami, hamam, medrese, darphane) yapıldı. Çalışmamızda Osmanlı arşiv belgeleri ışığında Nahçıvan Sancağının toplumsal ve ekonomik durumu ticaret ve zanaatlar ile şehirde yapılan eserler ve kurulan vakıflarla sancakta bulunan askeri birlikler gibi konulara yer verilecektir.

Anahtar Kelimeler: Nahçıvan, Osmanlı İmparatorluğu, sancak, Safevî Devleti, ekonomi, tarım, anıtlar.

\section{The Ottoman Rule in the Sanjak of Nahcivan in the $16^{\text {th }}$ and the $18^{\text {th }}$ Centuries}

\section{Abstract}

Nahcivan, a border region that witnessed bloody battles during the centuries of the Ottoman-Safavid rivalry, became a part of the Ottoman administrative structure twice in the period covered 1588-1603 and 17241735. In the Ottoman provincial administration, it was a sanjak (district) of the Revan eyalet (province). After the annexation of Nahcivan to the Ottoman realm, the province was called the "Revan and Nahcivan province" between 1588 and 1603.

\footnotetext{
*Araştırmacl, smbilge@gmail.com. (ORCID ID: 0000-0002-3609-936X) (Makale Gönderim Tarihi: 18.06.2017, Makale Kabul Tarihi: 13.08.2017)
}

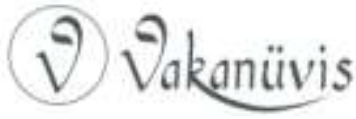


The sanjak of Nahcivan consisted of seven subdistricts (nahiye) and the city of Nahcivan that had twelve quarters (mahalle). The subdistricts were Gökçe, Mevâzi-i Hatun, Dereşahbûz, Arslanlu, Karabağ, Dereçam, and Bazarçayı. The economic life in the Nahcivan sanjak was based on agriculture and animal husbandry. The revenues from the sanjak - direct incomes of some of the villages and the salt mines and the taxes that were collected from council tax (ihtisab), dyeing place (boyahâne), candle mill (şemhâne), market dues (bâc-ı bazar), custom dues (tamgâ-i siyah), and poll-tax (cizye) were all transferred to the imperial treasury as the revenues (hass) of the sultan. Besides, some of the villages were granted to the janissaries that were stationed in the garrisons of the Revan and Nahcivan fortresses in the form of timar and zeamet in an exchange of their regular salaries (ulufe).

The Ottoman administration built a number of social, cultural, religious, and economic institutions in Nahcivan. These institutions included mosques, baths, madrasa, and mint. Based on the Ottoman archival records, this paper will demonstrate the social and economic life in the Nahcivan sanjak by putting an emphasis on the Ottoman institutions that were established in the region.

Keywords: Nahcivan, The Ottoman Empire, sanjak, The Safavid Empire, economy, agriculture, monuments.

\section{Giriş}

Aras Nehri'nin kollarından olan Nahcıvan çayının sağ kıyısında deniz seviyesinden 910 m. yükseklikte kurulmuş olan Nahçıvan, yüzyıllar boyunca çeşitli devletlerin hâkimiyetinde kaldı. ${ }^{1}$ 1501'de Safevî yönetimine giren Nahçıvan, Safevî ordusunun 23 Ağustos 1514'te Çaldıran Savaşı'nda yenilmesinden sonra 22 Eylül'de Osmanlı ordusu tarafından ele geçirildi ve Sultan I. Selim'in emriyle "ahalisinin Kızılbaş olması" nedeni ile yağmalandı. Osmanlı ordusunun bölgeden çekilmesi üzerine Nahçıvan'da Safevî yönetimi yeniden kuruldu.

Nahçıvan, Kanûnî Sultan Süleyman'ın Irakeyn Seferi denilen 1. İran Seferi (1534) ve 2. İran Seferi (1548) sırasında kısa süreler için yeniden Osmanlı Devleti'ne bağlandı. Kanûnî Sultan Süleyman'ın 28 Ağustos 1553'te çıktığı, İran'a yönelik üçüncü seferi olan ve Nahçıvan Seferi

\footnotetext{
${ }^{1}$ Nahçıvan hakkında bkz. V. Minorsky, "Nahçıvan”, IA, C. IX, 34-35; Hüsamettin M. Karamanlı, "Nahcivan", TDVIA, C. 32, 294-297.
}

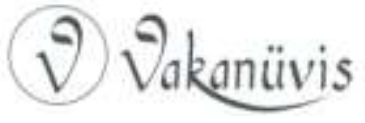


denilen 12. sefer-i hümâyûnunun hedefi ise doğrudan Nahçıvan oldu. (Resim 1) Kanûnî Sultan Süleyman komutasındaki Osmanlı ordusu 28 Temmuz 1554'te Nahçıvan'ı yeniden fethetti. Halkının büyük bölümü kaçan Nahçıvan şehri, Mart-Eylül 1553'te Aras nehrinden Van Gölü'ne kadar Osmanlı topraklarına taarruz ederek Ahlat, Adilcevaz, Erciş ve Bargiri kalelerini işgâl eden Safevîlerin, "hudud-ı mahrûse sükkânına ol cânibden vâki olan mezâlim-i fecâyi'ün mükâfâtı içün" iki gün boyunca şehir yerle bir oluncaya kadar yıkılıp yağmalandı. Civardaki köyler ve tarlalar yakılıp yıkıldı. Ramazan ayının başlaması üzerine pâdişâh yağmaya son verdi. Nahçıvan, Amasya Barışı (1555) ile yeniden Safevî yönetimine girdi.

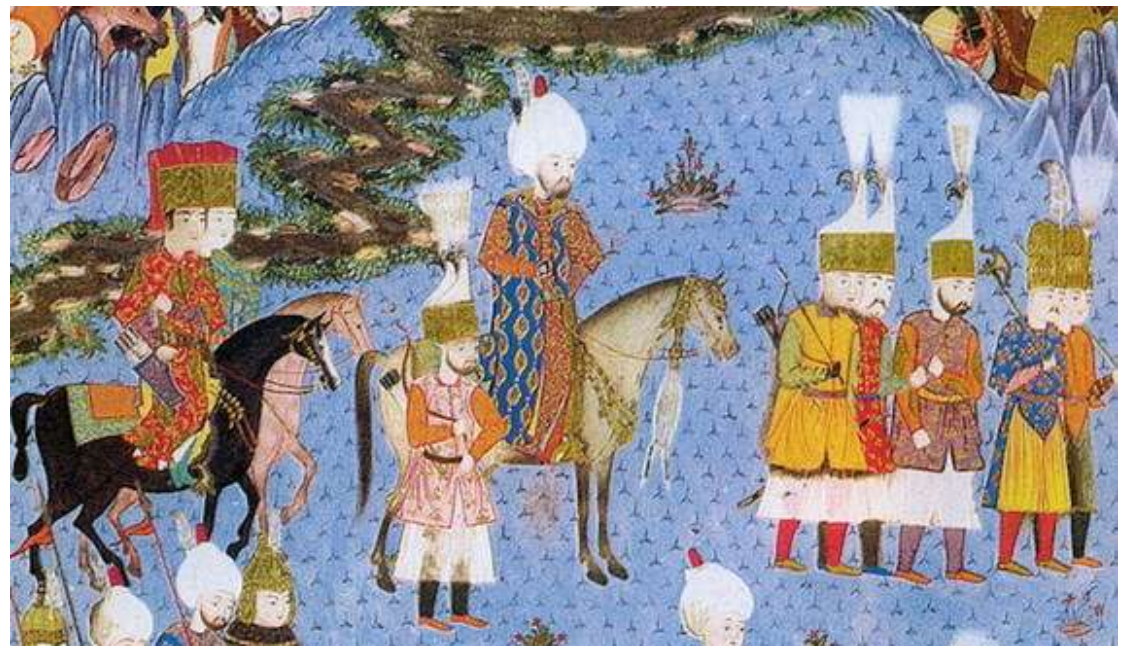

Resim 1. Kanunî Sultan Süleyman Nahçıvan Seferi'nde.

\section{Yüzyılın Sonunda (1588-1603) Nahçıvan Sancağı}

Sultan III. Murad dönemindeki Osmanlı-Safevî savaşları (1578-1590) sırasında topraklarının daha fazla tahrip olmasını istemeyen yerli halkın isteği ile 1586'da Osmanlı Devleti'ne katılan Nahçıvan bölgesi bir sancak olarak, yeni kurulan Revân ve Nahçıvan Eyâleti'ne bağlandı. 1587-1588 kışında Safevîlerin geri aldığı Nahçıvan, Deli Hızır Paşa tarafından 1588 'de bir kere daha fethedilerek yeniden Revân ve

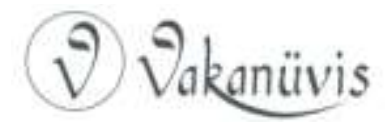


Nahçıvan Eyâleti olarak da adlandırılacak olan Revân Eyâleti'ne bağlandı.

\section{Nahçıvan Sancağı'nın İdarî Taksimatı}

Revân Eyâleti'nin tahriri, Mal Defterdârı Mehmed Efendi ve Dîvân-ı Hümâyûn Mal Kâtiblerinden Hasan Ağa tarafından yapıldı ve 999 Muharrem ayı sonlarında (18-27 Kasım 1590) tamamlanarak eyâletin toprakları ve üzerinde yaşayan halk deftere kaydedildi. ${ }^{2}$ Revân Eyâleti'ne bağlanan Nahçıvan Sancağı; Nahçıvan kazâsı ile Dereşahbûz, Gökçe, Mevâzi-i Hatun, Arslanlu, Karabağ, Dereçam ve Bazarçayı nâhiyelerinden meydana geliyordu. Kazâ ve nâhiyelerden sadece Nahçıvan'ın kendi adını taşıyan nefsi bulunmaktaydı. Dereşahbûz ve Karabağ birer kasaba durumundaydılar. Kendi adlarını taşıyan yerleşim merkezi olmayan Arslanlu, Mevâzi-i Hatun, Dereçam, Gökçe ve Bazarçayı ise yalnızca idarî bölge ismi olarak kaydedilmişlerdi.

Söz konusu tahrire göre Nahçıvan kazâsına bağlı 21'i meskûn, 13'ü muhtemelen Osmanlı-Safevî savaşları sırasında ahalisi tarafından boşaltılmış olan (hâli) 34 köy vardı. Meskûn köylerde 418'i Müslüman, 75'i Ermeni olmak üzere toplam 493 hâne ve tümü Müslüman 58 mücerred yaşamaktaydı.

\section{Nahçıvan Şehri}

Nefs-i Nahçıvan, 1590 tahririne göre Kal'a ile birlikte 12 mahalleden meydana geliyordu. Söz konusu mahalleler; Hocabey (107 hane ile en kalabalık mahalle), Kâdı Cihan/Hoca Mirican, Seyyid Hüseyin, Keke Tâver, Künbed/Türkmenler, Molla Ahmedî, Mirzâbey/Mahalle-i Câmi, Şahab, Huzemerk, Balâ, Tizhiran (10 hane ile en düşük nüfusa sahip olan mahalle) ve Mahalle-i Gebrân'dı. Nahçıvan toplam 745 hâneye

\footnotetext{
${ }^{2}$ BOA (Başbakanlık Osmanlı Arşivi), TTD (Tapu Tahrir Defterleri) No. 633; Muharrem 999 (Kasım 1590) tarihli ve 393 sayfadır. 15, 95, 98-99, 131, 134, 137, 138, 157, 163, $181,197-199,213,239,253,259,325,329,339,366,367$ ve 387. sayfaları boş olan, tuğrası bulunmayan ve dua (s. 2-3) ile başlayan bu mufassal defterin başında (sayfa 412) Revân kanunnâmesi yer almaktadır. Bu tahrire dayanarak hazırlanan bir yüksek lisans tezi mevcuttur. Hakan Karagöz, 1590 Tahririne Göre Nahçıvan Kazası, Süleyman Demirel Üniversitesi Sosyal Bilimler Enstitüsü, Yayınlanmamış Yüksek Lisans Tezi, Isparta 2001.
}

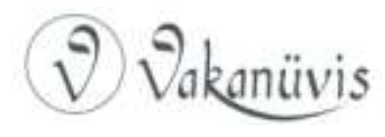


sahip, \% 81,5'i Müslüman, \% 18,5'i Ermeni (141 hâne) olmak üzere 4000 kadar nüfusu olan bir şehirdi. ${ }^{3}$

Şehirde dört cami (Câmi-i Kebîr, Câmi-i Kızıl Arslan, Câmi-i Sufî Halil, Câmi-i Mehmed Kethudâ) bulunmaktaydı. Ayrıca yedi mescid (Mescid-i Ağa, Mescid-i Hoca Halil, Mescid-i Keçeci, Mescid-i Mahalle-i Ahmedî, Mescid-i Sultan Mahmud, Mescid-i Ismailân, Mescid-i Hacı Salli, Mescid-i Basrî, Mescid-i Şeyh Emineddin, Mescid-i Etmelik) vardı. Osmanlı hâkimiyeti altında olduğu dönemde Nahçıvan şehrinde Osmanlı idarecileri tarafından birçok bina inşâ ettirildi. Evliya Çelebi, "İslâmbol tarzı" üzere inşâ edilmiş Cenâbî Ahmed Paşa Camisi ve hamamı, Ferhâd Paşa Camisi, Güzel Ali Paşa Camisi, Cağaloğlu Yusuf Sinan Paşa Camisi, Hadım Câfer Paşa Camisi ve övgüyle bahsettiği Zâl Paşa Hamamı́nın bulunduğunu yazar. ${ }^{4}$

Osmanlı-Safevî savaşları sırasında tahrip olan Nahcıvan Kalesi yerli halkın da yardımıyla 1589 yılında yeniden inşâ edildi. Bölgede görev yapan askerlere yapılacak maaş ödemeleri ve garnizonlar için yapılacak alımlarda kullanılacak paraların, İstanbul'dan ve diğer merkezlerden bölgeye sevki sırasında yaşanan lojistik ve güvenlik sıkıntıları ve maliyetler, çağdaş Osmanlı belgelerine yansıyacak kadar yüksekti. ${ }^{5}$ Muhtemelen bu sıkıntıları aşabilmek üzere Revân ile birlikte Nahçıvan'da da bir darphâne kurularak, Sultan III. Murad ve Sultan III. Mehmed adına gümüş paralar basıldı. ${ }^{6}$

Nahçıvan'da şehir halkı ile esnâf ve zanaatkârların ihtiyaçlarını temin etmek amacıyla dokumacılıkta kullanılan ipliklerin ve kumaşların boyanması için bir boyahâne, hayvanların kuyruk ve iç yağlarından mum üretilen bir şemhâne, yine hayvanların kuyruk ve iç yağlarından sabun imal edilen bir sabunhâne bulunmaktaydı. Şehirde ayrıca, şarap

\footnotetext{
${ }^{3}$ BOA. TTD 633. s. 100-107.

${ }^{4}$ Evliyâ Çelebi, Seyahatnâme, C. II (Yay. Yücel Dağlı-Seyit Ali Kahraman, Robert Dankoff), İstanbul 2002. 119.

5 "Memâlik-i mahrûseden ol kal'elere bir iki yüz yük akça (100-200 milyon akça) lâzımdır.. Ânı dahi alub gitmeğe her bir kal'aya başka bir asker gerekdir. Allah saklaya yine de gâret ve hasâretten dahi emîn olmazlar.. Bu kal'alara nereden ve neçeye dek hazîne ve zahîre ve asker gönderilür? [Koca Sinan Paşa'nın Telhisleri, (Yay. Haz. Halil Sahillioğlu), İstanbul 2004, No. 105, 146-147.]

${ }^{6}$ Cüneyt Ölçer, Sovyet Rusya Müzelerindeki (Moskova ve Leningrad) Nadir Osmanlı Madeni Paraları, İstanbul 1972, 25-26.
}

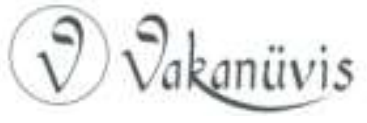


üretilen bir meyhâne, hayvanların kesilip satıldığı bir kasaphâne, kesilen hayvanların baş ve ayaklarının toplanıp satıldığı bir başhâne vardı. Nahçıvan'ın şehir ve ticaret vergileri (ihtisab, bâc-ı bazar, tamgâ-i siyah) ile boyahâne ve şemhâne gelirleri pâdişâh hâslarına dâhildi. Ermeni halk hem cizye hem de nefer (yetişkin erkek) başına 2 akça marhasiyye denilen bir kilise vergisi ödüyorlardı. Nahçıvan Sancağı'nın cizye vergisi geliri pâdişâh hâslarına dâhildi.

Nahçıvan'da Vatikan'a bağlı bir Katolik piskoposluğu vardı. 14. yüzyılda Dominikenler, aralarında rahiplerin de bulunduğu birçok Nahçıvan Ermenisi'ni Katolik yapmaya muvaffak olmuşlardı. ${ }^{7}$ Dominiken tarikatının Ermeni dalı olan ve Fratres Unitores (= Unitor Kardeşler, Erm. Unitork) adı verilen Katolik keşişler tarafından 1344'te kurulmuş olan, ayin ve ibadetlerin Ermenice yapıldığı uniat bir kilise olan bu piskoposluk, Osmanlı Kafkasyası'nda tek Katolik varlıktı. Burada görevli Dominiken tarikatına mensup keşişler, Papalık ile Safevî Devleti arasında diplomatik faaliyet de gösteriyorlardı.

\section{Nahçıvan Sancağı'nda Kırsal Hayat ve Tarım}

Yukarıda da ifade edildiği üzere 1590 'da Nahçıvan kazâsına bağ|ı 21'i meskûn, 13'ü ahalisi tarafından boşaltılmış (hâli) 34 köy vardı. Nahçıvan'a bağlı bazı köylerin gelirleri pâdişâh hâslarına, Çulha ve Çivan gibi bazı köylerin gelirleri paşmaklık olarak valide sultan hâslarına dâhildiler. ${ }^{8}$ Halkı kaçmış ve geliri az köyler ise ulûfeleri hazîneye kalmak şartı ile Nahçıvan Kalesi'nde görev yapan askerlere timar ve zeâmet olarak verilmişti. Karabağ ahâlisi gelip geçenlere hizmet ettikleri için avârız-ı dîvâniye ve tekâlif-i örfiyyeden muâftılar. 1590 'da Nahçıvan'da 36 adet değirmen ve 2 adet bezirhâne (bulgur değirmeni) bulunmaktaydı.

Köy evleri tek katlı düz toprak damlı, kerpiç yapılardı. Bağcılık ve bahçecilik yapılan bazı bölgelerde " $U$ " ya da dikdörtgen şeklinde yapılmış, iki katlı, düz toprak damlı, pencereli evler bulunmaktaydı. Bu evlerin çatısına dıştan yapılmış taş veya tahta bir merdivenle çıkılırdı.

\footnotetext{
${ }^{7}$ George Bournoutian, Ermeni Tarihi Ermeni Halkının Tarihine Kısa Bir Bakış, (Çev. Ender Abadoğlu-Ohannes Kılıçdağı), İstanbul 2011, s. 127.

${ }^{8}$ BOA. ibnülemin Saray Mesâlihi, No. 1234; Osmanlı Arşiv Belgelerinde Nahçıvan, İstanbul 2011, 36-37.
}

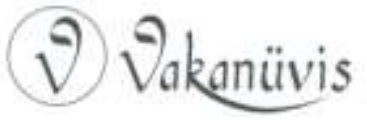


Çok sıkı kümelenmiş, çoğu zaman birbirlerine 2-3 taraftan bitişik şekilde inşâ edilmiş olan evlerin yola bakan cepheleri kerpiçten yapılmış yüksek bir duvarla korunmuştu. Bu duvarın arkasında bir avlu (Ermenice: pag) yer alırdı. ${ }^{9}$

1590 tarihli deftere göre Nahçıvan'da şehir merkezinde 14 tam ve bir yarım (nim) çiftlik, kazaya bağlı köylerde 12 tam çiftlik ve 9 mezrâ bulunmaktaydı. Nahçıvan'da 160 bennâk (nim-çiftten az arazi tasarruf eden -ekinlü bennak- ya da hiç arazi tasarruf etmeyen -caba bennakevli reâya) vardı. Her yıl mart ayında; çiftlik tasarruf edenler 50 akça, nim çiftlik tasarruf edenler 25 akça, ekinlü bennâkler 18, caba bennâkler 12 akça vergi ödüyorlardı. ${ }^{10}$ Gayrimüslim reâya ise çift resmine karşılık olarak, cizye ile birlikte tasarruf ettikleri arazinin büyüklüğüne bakılmaksızın 25 akça ispençe resmi ödemekteydiler. ${ }^{11}$ Mezrâlardan ise her yıl ekilen verimli yerden 2 dönüme bir akça, verimsiz yerden 3 dönüme 1 akça dönüm resmi alınıyordu. ${ }^{12}$

1590'da sancakta buğday, arpa, darı, bakliyat (mercimek, nohut), sebze-meyve, keten ve yedi türlü pamuk üretiliyor, bağcılık ve arıcılık yapılıyordu. Narh fiyatı 8 akça olan buğdaydan ve narh fiyatları altışar akça olan arpa ve darıdan humus tabir edilen üretimin $1 / 5$ ile $1 / 8$ arasında değişen oranlarda kadar öşür alınıyordu. Mercimek ve nohudun narh fiyatı 8 akça, pirincin narh fiyatı 30 akça, ölçü birimi menn (16. ve 17 . yüzyıllarda 2,9 kg., 18 . yüzyılda $3 \mathrm{~kg}$.) olan pamuğun narh fiyatı menn başına 96 akça, üzüm bağlarından elde edilen ve ölçü birimi menn/menn-i köhne (4,3 kg.) olan şıranın narhı ise beş akçaydı. Âdet-i ağnam (koyun vergisi), her Nisan ayında iki koyuna 1 akça alınır, koyun kuzusu ile birlikte sayılırdı. Resm-i kevvâre (kovan vergisi), iyi kovandan 2 akça, verimsiz kovandan 1 akça olarak alınıyordu. Değirmen vergisi (Resm-i âsiyâb) ise harman vaktinde alınmak üzere ayda 5 akça (= 60 akça) olarak tahsil ediliyordu. Resm-i bezirhâne de 60

\footnotetext{
${ }^{9}$ Marry Kilbourne Matossian-Susie Hoogasian Villa, Anlatılar ve Fotoğraflarla 1914 Öncesi Ermeni Köy Hayatı, (Çev. Altuğ Yılmaz), İstanbul 2006, 41, 88.

${ }^{10}$ BOA. TTD 633. s.4.

${ }^{11}$ BOA. TTD 633. s.5.

${ }^{12}$ BOA. TTD 633. s.6.
}

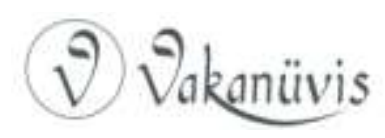


akça idi. Sancakta tuz ocakları işletilmekte olup, bunların gelirleri pâdişâh hâslarına dâhildii. ${ }^{13}$

\section{Nahçıvan Sancağı'nın Sonu}

Nahçıvan Sancağı, Şâh I. Abbâs'ın komutanlarından Karamanlı Zülfikar Han'ın, 26 Ekim 1603'te Revân Beylerbeyi Şerif Mehmed Paşa'nın önceden boşalttığı Nahçıvan şehrini işgâl etmesiyle son buldu.

Nahçıvan işgâl edildikten sonra Osmanlılara yardımcı olduklarından dolayı şehirdeki Sünni mahallesinde katliam yapıldı. ${ }^{14}$ Nahçıvan civarındaki köyler, Osmanlı ordusunun bölgede insan, yiyecek ve hayvanlarına yem bulamaması için Safevîler tarafından boşaltılarak yakıldı. Sünniler katledilirken, Ermeniler İran topraklarına sürüldüler. Bölgede tarım ve iktisadî hayat "Sazlıkta rüzgârla yayılan alev gibi" mahvoldu. Sünnî Müslümanlara ve Ermenilere büyük zulüm uygulayan Şâh I. Abbâs, Nahçıvan Ermenilerinin çoğunu 1604'te İran'a sürdü. Çok sayıda Ermeni Aras nehrini geçerken hayatını kaybetti. ${ }^{15}$ Nahçıvan, Sultan IV. Murad'ın Revân Seferi sırasında (1635) Osmanlı orduları tarafından kısa bir süre için ele geçirildi. Tavernier, şehrin IV. Murad'ın orduları tarafından bütünüyle harabeye çevrildiğini, hatta camilerin bile yakıldığını söylemektedir. ${ }^{16}$

\section{Yüzyılda (1724-1735) Nahçıvan Sancağı}

Yıkılmak üzere olan Safevî Devleti'nin Kafkasya ve Batı İran'daki topraklarını paylaşmak üzere Osmanlı Devleti ile Rusya arasında, 1722 'de başlayan diplomatik görüşmeler neticesinde 24 Haziran 1724 'te İran'ın paylaşılması hakkında istanbul Mukâsemesi imzalandı. Bu anlaşma ile iki devlet arasında Kür nehri sınır kabul edildi. Kartli, Kahet, Şirvan, Gence, Revân, Karabağ ve Nahçıvan Osmanlı Devleti'ne

\footnotetext{
${ }^{13}$ BOA. TTD 633, çeşitli yerler.

14 "Sünni nâmına olanların hânelerine girdiler ve buldukların nehb ü gâret ve önlerine gelen reâyâya küllî zulm ü hasâret eylediler." [Mustafa Naîmâ, Târih-i Naîmâ (Ravzatü'lHüseyin fi hulâsat-i Ahbâri'l-Hâfikayn), (Haz. Mehmet İpşirli), C. I, Ankara 2007, 249.]

${ }^{15}$ Arakel de Tauriz, Livres d'histoires, (Trans. M.F. Brosset) St. Petersburg 1874'ten Bekir Kütükoğlu, Osmanlı-Iran Siyasî Münasebetleri (1578-1612), İstanbul 1993, 271272.

${ }^{16}$ Jean-Baptiste Tavernier, Tavernier Seyahatnamesi, (Ed. Stefanos Yerasimos), (Çev. Teoman Tunçdoğan), İstanbul 2006, 79.
}

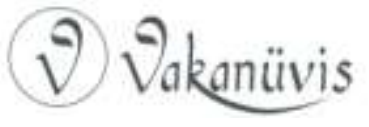


bırakıldı. ${ }^{17}$ Nahçıvan, Bayezid Sancakbeyi Mahmud Paşa ve Eleşkirt Sancakbeyi Halil Bey tarafından 11 Ağustos 1724'te bir kere daha fethedilerek Osmanlı topraklarına katıldı ve 1724-1735 yılları arasında Revân Eyâleti'nin bir sancağı oldu

\section{Nahçıvan Sancağı'nın İdarî Taksimatı}

Revân Eyâleti'nin tahririne Rakka Valisi ve Tebriz Seraskeri Abdullah Paşa ile Silahdâr Kâtibi, Tebriz Defterdârı ve Muharriri Mustafa'ya gönderilen hükme göre Mart $1726^{\prime}$ da başlandı. ${ }^{18}$ Revân şehri ve kırsalındaki halkın savaş ve karışıklıklar yüzünden yerlerini terk etmeleri nedeni ile yeniden yapılan ${ }^{19}$ tahrir ancak 1728 yılında bitirildi. ${ }^{20}$ Revân Eyâleti'ne bağlı Ordubad Sancağı da bir süre sonra lağvedilerek, Ordubad, Bazarçayı ve Ağcakale nahiyeleri olarak Nahçıvan Sancağı'na ilhâk edildi.

Nahçıvan Sancağı, Zengezur dağlarından Aras nehrine kadar uzanan toprakları kaplıyordu. Sancak, şehirle birlikte 8 köy ve 3 mezrâdan oluşan Nahçıvan, 5'i hâli 17 köyü ile 3 mezrâsı olan Kışlağat, 5'i hâli 17 köy ve 3 kışlaktan oluşan Karabağ, 12 köy, 2 mezrâdan oluşan Mevâzi, 9 köyden meydana gelen Mevâzi-i Hatun, 4 köyü olan Dereçam, 8 köyü olan Arslanlı Mülkü, 21 köy ve 2 mezrâdan meydana gelen Dereşahbûz, 5 köyü olan Derenorküt, 41 köy ve bir yaylaktan oluşan Sisyan, Elince çayının sağ kıyısında $1700 \mathrm{~m}$. yüksekliğindeki Elince Dağı üzerinde kurulmuş Elince Kalesi ile 26 köy ve 1 mezrâdan oluşan Elince, 97 köy ve 3 mezradan meydana gelen Dereleyez, bir kazâ (Ordubad) ile 8'i hâli 37 köyü olan Âzad-ceyrân ve 5 köyü olan Şorlut nâhiyelerinden meydana geliyordu. ${ }^{21}$ (Harita1)

\footnotetext{
${ }^{17}$ Küçükçelebizâde Asım, Târih, i̇stanbul 1865, 149-169.

${ }^{18}$ BOA. ADVN. MHM. d, MD (Mühimme Defteri) No. 132, Hk. 2.

${ }^{19}$ BOA. ibnülemin Dâhiliye, No. 2128.

${ }^{20}$ BOA. TTD. No. 898. Başında Sultan III. Ahmed'in tuğrası bulunan 1140/1728 tarihli 898 numaralı icmal defteri 170 sayfadır. Defterin sonunda Revân eyâletindeki Pâdişah hasları, mîr-i mîrân hasları, timar ve zeametlerle, "mamur" ve "hâli" köylerin, Şüregel ve Nahçıvan livaları Pâdişah hasları kayıtları bulunmaktadır. Ziya Bünyadov-Hüsamettin Memmedov, Naxçıvan Sancağının Müfessel Defteri. 9 maharram 1140 (27 avqust 1727), Bakı 1997. Hüsamettin Memmedov, Irevan Eyaletinin Ícmal Defteri, Bakı 1996.

${ }^{21}$ BOA. TTD. No. 898.
}

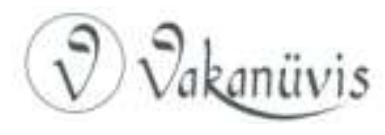




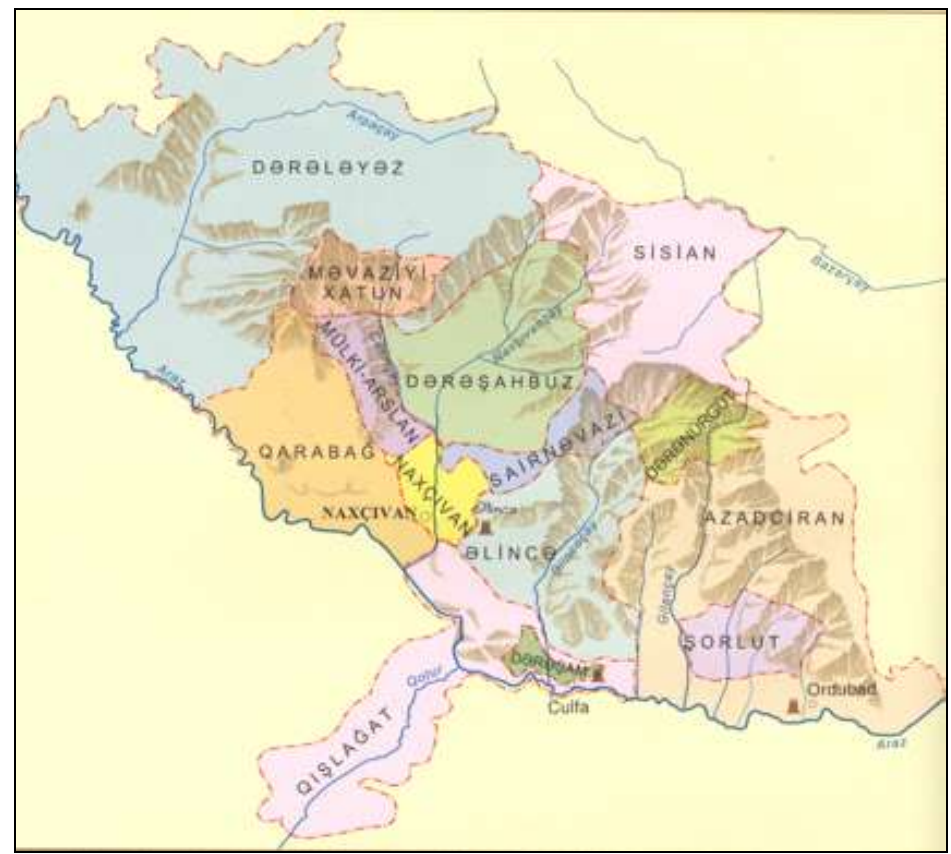

Harita 1. Nahçıvan Sancağı'nın İdarî Taksimatı (1724-1735).

Sancaktaki toplam hâne sayısı 6048'di. Sancağın nüfusu ise \% 60'ı Müslüman/Türk, \% 30'u Ermeni, kalanı Sünnî ve Yezidî Kürt ve Yahudi olmak üzere 30.000 kadardı.

Nahçıvan Sancağı'ndaki çeşitli gelir kaynakları mukataa hâline getirilerek kayıt ve hesaplarını gösteren mukataa defteri hazırlandı. ${ }^{22}$ Sancakta savaş nedeni ile kaçan halk tarafından boşaltılan veya harap olan yerler "ihyâ edilmek üzere" savaşta yararlılıkları görülen askerlere ve resmi görevlilere zeamet ve timar olarak tevcih edildi. Anılan tevcihlere ait zeamet ve timar tahrir defterleri hazırlanıp İstanbul'a gönderildi. ${ }^{23}$ Nahçıvan'da görevli yeniçerilerin bir bölümüne de ulûfelerine karşılık olarak timar verildi. ${ }^{24}$

\footnotetext{
${ }^{22}$ BOA. MAD. d, (Maliyeden Müdevver Defterler) No. 3307, 3308.

${ }^{23}$ BOA. MAD. d, No. 17670.

${ }^{24}$ BOA. MAD. d, No. 15271.
} 


\section{Nahçıvan Şehri}

Nahçıvan şehri, 1727 yılında Yukarı Mahalle ve Aşağı Mahalle isimli iki mahalleden müteşekkildi. Yukarı Mahalle'de 399 Müslüman hâne, Aşağı Mahalle'de ise 390 Müslüman ve 78 Gayrimüslim hâne vardı. ${ }^{25}$ Osmanlı şehirlerinin bazılarında toplumsal farklılıklara göre yukarı mahalle-aşağı mahalle şeklinde bir bölümlenme söz konusudur. Her mahallenin bir ötekisi vardır. Nahçıvan'daki Yukarı Mahalle, şehrin yerli Şiî halkının, Aşağı Mahalle, Şiî ahali dışında Osmanlı memur ve askerlerinin aileleri ile şehrin yerli Gayrimüslim ve Sünnî halkının ikamet ettikleri kesimi idi. 4500 kadar nüfusu olan Nahçıvan şehrinde nüfusun \% 91'ini Müslümanlar, \% 9'unu Hıristiyan Ermeniler teşkil ediyorlardı.

Nahçıvan şehrinde 1727 'de bir boyahane, bir şemhâne, bir sabunhâne, dört çarşı (Meydan, Hatip, Çakan ve Börekçi çarşıları) ve bir pazar yeri (Şeytan Pazarı) ile hamamlar bulunmaktaydı. Şehirde kiraları Câmi-i Kebîr/Sultan Murad, Hızır Paşa camilerine ve Hâce Barak köyündeki camiye vakfedilmiş olan, içlerinde bakkal, kasap, şekerci, aktar, berber, kürkçü, basmacı, pabuççu, terzi, demirci, bakırcı, kılıççı gibi esnaf ve zanaatkârların faaliyet gösterdiği toplam 198 dükkân vardı. ${ }^{26}$ Geliri yetersiz olan sancaktaki yukarıda adı geçen üçü dışında vakfı olmayan cami, mescid ve medreselerde görev yapan imam, hatip, müezzin, müderris ve hizmetlilerin ücretleri, Erzurum Gümrüğü ile Erzurum kassabiye, ihtisab-ı mizân-ı harir ve beyt-ül mâl-i hassa gelirlerinden ödeniyordu. ${ }^{27}$

\section{Nahçıvan Sancağı'nın Sonu}

Nahcıvan ve civarındaki ikinci Osmanlı yönetimi de (1724-1735) ilki gibi fazla uzun sürmedi. Osmanlı-İran savaşlarında (1722-1746) bir serhad sancağı durumunda olan Nahçıvan Sancağı, Nâdir Han komutasındaki İran ordusunun Ekim 1735'te Nahçıvan'ı işgâliyle son buldu.

\footnotetext{
${ }^{25}$ Bünyadov-Memmedov, a.g.e., s. 37-50.

${ }^{26}$ BOA. TTD. No. 905. s. 23-24; BOA. Evkâf Haremeyn Muhasebesi Defterleri Gömlek No 2928.

${ }^{27}$ BOA. D.BŞM d, No. 1561.
} 


\section{Sonuç}

Nahcıvan şehri ve civarı 16-18. yüzyıllardaki Osmanlı-Safevî savaşları sırasında birçok kez el değiştirmiş, hem bölge hem de bölgede yaşayan halk söz konusu savaşlardan çok etkilenmiştir. Nahçıvan'da 16. yüzyılda (1588-1603) ve 18. yüzyılda (1724-1735) doğrudan Osmanlı idarî yapılanması tesis edilerek, toprak yönetimi ve vergilendirme alanında Osmanlı düzeni uygulanmış ve Osmanlı idarecileri tarafından bazı kamusal yapılar inşa edilmiş, ancak her iki idarî yapılanma da kısa süreli olmuştur. 1826 yılına kadar İran'ın 1826'dan 1991'e kadar Rus Çarlığı ve SSCB'nin bir parçası olan Nahçıvan, günümüzde Azerbaycan'a bağlı bir özerk cumhuriyettir.

\section{Kaynakça}

\section{Arşiv Belgeleri:}

BOA. Tapu Tahrir Defterleri (TTD) No. 633, 898, 905.

BOA. Maliyeden Müdevver Defterler (MAD) No. 3307, 3308. 15271, 17670.

$B O A$. Mühimme Defterleri (MD) No. 132.

BOA. Bâb-ı Defteri Defterleri (D.BŞM) No. 1561.

BOA. Evkâf Haremeyn Muhasebesi Defterleri No 2928.

BOA. İbülemin Dâhiliye, No. 2128.

$B O A$. İbnülemin Saray Mesâlihi, No. 1234.

\section{Yayınlanmış Belgeler:}

Bünyadov, Ziya -Hüsamettin Memmedov, Naxçıvan Sancağının Müfessel Defteri. 9 maharram 1140 (27 avqust 1727), Bakı 1997.

Koca Sinan Paşa'nın Telhisleri, (Yay. Haz. Halil Sahillioğlu), ìstanbul 2004.

Memmedov, Hüsamettin, Irevan Eyaletinin Ícmal Defteri, Bakı 1996.

Osmanlı Arşiv Belgelerinde Nahçıvan, İstanbul 2011.

\section{Kaynaklar:}

Evliyâ Çelebi, Seyahatnâme, C. II (Yay. Yücel Dağlı-Seyit Ali Kahraman, Robert Dankoff), i̇stanbul 2002.

Küçükçelebizâde Asım, Târih, İstanbul 1865.

Mustafa Naîmâ, Târih-i Naîmâ (Ravzatü'l-Hüseyin fi hulâsat-i Ahbâri'lHâfikayn), (Haz. Mehmet İşirli), C. I, Ankara 2007.

Tavernier, Jean-Baptiste, Tavernier Seyahatnamesi, (Ed. Stefanos Yerasimos), (Çev. Teoman Tunçdoğan), İstanbul 2006.

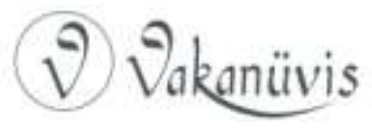




\section{Araştırmalar (Kitap, Tez ve Makaleler):}

Bournoutian, George, Ermeni Tarihi Ermeni Halkının Tarihine Kısa Bir Bakış, (Çev. Ender Abadoğlu-Ohannes Kılıçdağı), İstanbul 2011.

Karagöz, Hakan. 1590 Tahririne Göre Nahçıvan Kazası, Süleyman Demirel Üniversitesi Sosyal Bilimler Enstitüsü, Yayınlanmamış Yüksek Lisans Tezi, Isparta 2001.

Karamanlı, Hüsamettin M. “Nahcıvan”, TDViA, C. 32.

Kütükoğlu, Bekir, Osmanlı-iran Siyasî Münasebetleri (1578-1612), İstanbul 1993.

Matossian, Marry Kilbourne-Susie Hoogasian Villa, Anlatılar ve Fotoğraflarla 1914 Öncesi Ermeni Köy Hayatı, (Çev. Altuğ Yılmaz), İstanbul 2006.

Minorsky, Vladimir, "Nahçıvan", iA, C. IX.

Ölçer, Cüneyt, Sovyet Rusya Müzelerindeki (Moskova ve Leningrad) Nadir Osmanlı Madeni Paraları, İstanbul 1972. 